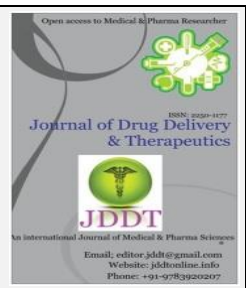

Open Access

Research Article

\title{
Difference Spectrophotometric Method for Estimation of Amitriptyline Hydrochloride in Bulk Drug
}

\author{
Kaderkar Dattatray,* Tamboli A.M., Kale Seema, Jadhav Poonam, Kale Kishori
}

Department of Pharmaceutical Chemistry, Sahyadri College of Pharmacy Methwade, Sangola, University of Solapur, Solapur, Mahar ashtra, India

\begin{abstract}
A simple, precise and sensitive UV method has been developed for the estimation of Amitriptyline Hydrochloride in bulk drug form by Difference Spectroscopic method. Amitriptyline Hydrochloride has exhibited maximum absorbance at about $239 \mathrm{~nm}$ in acidic and basic media. Beer's law was obeyed in the concentration range of $(2-10) \mu \mathrm{g} / \mathrm{ml}$ in both cases. The proposed method was successfully applied for the determination of Amitriptyline Hydrochloride in bulk drug. As per ICH guidelines the results of the analysis were validated statistically and were found to be satisfactory.
\end{abstract}

Keywords: Amitriptyline Hydrochloride, Difference Spectrophotometry, Validation, Bulk, Linearity.

Article Info: Received 11 July 2019; $\quad$ Review Completed 20 Aug 2019; $\quad$ Accepted 24 Aug 2019; Available online 30 Aug 2019

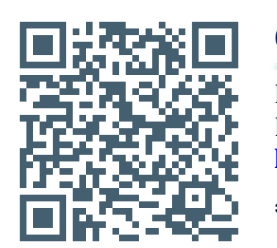

Cite this article as:

Kaderkar D, Tamboli AM, Kale S, Jadhav P, Kale K, Difference Spectrophotometric Method for Estimation of Amitriptyline Hydrochloride in Bulk Drug, Journal of Drug Delivery and Therapeutics. 2019; 9(4-A):301-304 http://dx.doi.org/10.22270/jddt.v9i4-A.3475

Kaderkar Dattatray, Department of Pharmaceutical Chemistry, Sahyadri College of Pharmacy Methwade, Sangola, University of Solapur, Solapur, Maharashtra, India

\section{INTRODUCTION:}

Amitriptyline is chemically 3-(10, 11-dihydro-5H-dibenzo [a, d] cycloheptene-5-ylidene)- $\mathrm{N}, \mathrm{N}$-dimethylepropane-1-amine. Amitriptyline is tricyclic antidepressant. It is used in the treatment of migraine and neuropathic pain such as fibromyalgia and postherpetic neuralgia and less commonly in insomnia. It is also used for number of medical conditions including major depressive disorders. It may be more effective than other antidepressants, including selective serotonin reuptake inhibitor (SSRI's). Amitriptyline is rarely used as a first line antidepressant due to higher toxicity to overdose and generally poorer tolerability. It is used as a second line treatment when selective serotonin reuptake inhibitors do not work. It is used in addition to other medication for pain. ${ }^{1}$ Amitriptyline is popular off-label treatment for irritable bowel syndrome (IBS).the essential feature of differential spectroscopic assay is that the measured value is the difference in absorbance between two equimolar solutions of analyte in different chemical forms which exhibit different spectral characteristics and follows Beers law. ${ }^{2}$<smiles>CN(C)CCC=C1c2ccccc2CCc2ccccc21</smiles>

Molecular formula $\mathrm{C}_{20} \mathrm{H}_{23} \mathrm{~N}$

Molecular weight: $277.4 \mathrm{gm} / \mathrm{mol}$

Figure 1: Structure of Amitriptyline

\section{Objectives}

Amitriptyline shows improved absorbing interference by the technique of difference spectroscopic method. Thus objectives of the present study was to develop new analytical different spectroscopic method and it's validation parameter for the proposal method according to ICH guidelines for the estimation of Amitriptyline drug. 


\section{Materials and Methods}

\section{Chemicals and reagent}

Amitriptyline [bulk drug] used were of analytical reagent grade purchased from Reagent Lab fine Chemical Industries Mumbai, India, $\mathrm{NaOH}$ and $\mathrm{HCl}$ were purchased from Poona chemical laboratory and Double distilled water was used throughout the analysis.

\section{Instrumentation}

A shimadzu 1800 UV/VIS double beam spectrophotometer with $1 \mathrm{~cm}$ matched quartz cells was used for all spectral measurements.

\section{Selection of common solvent}

$0.1 \mathrm{~N} \mathrm{HCl}$ and $0.1 \mathrm{~N} \mathrm{NaOH}$ were selected as a common solvent for developing spectral characteristics of drugs.

\section{Preparation of solution}

Standard stock solution containing Amitriptyline Hydrochloride was prepared by dissolving $10 \mathrm{mg}$ in $100 \mathrm{ml}$ of distilled water and then diluted with $0.1 \mathrm{~N} \mathrm{HCl}$ and $0.1 \mathrm{~N}$ $\mathrm{NaOH}$ separately to get series of dilution ranging from 2-10 $\mu \mathrm{g} / \mathrm{ml}$ and then absorbance recorded at $239 \mathrm{~nm}$.calibration curve was prepared by plotting concentration versus difference in absorbance and found to be linear in the concentration range of $2-10 \mu \mathrm{g} / \mathrm{ml}$.

\section{Method Validation}

For the validation of proposed analytical method, the parameters were taken into consideration are Accuracy,
Precision, Linearity, Limit of Detection (LOD), Limit of Quantitation (LOQ), Range. ${ }^{10}$

\section{Beers law limit $(\mu \mathrm{g} / \mathrm{ml})$}

$2 \mu \mathrm{g}-10 \mu \mathrm{g}$

\section{Linearity}

From the plotted calibration curve and by measuring the absorbance's of the spectrum from serial dilutions of each drug at their respective wavelength.

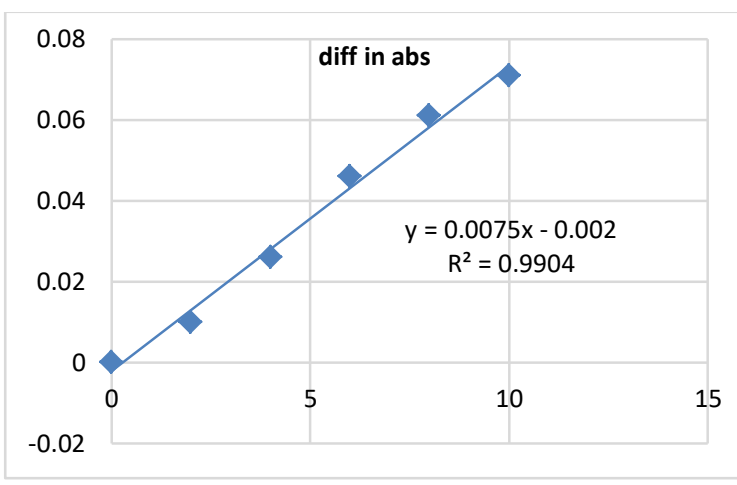

Figure 2: Calibration Curve of Amitriptyline

\section{Accuracy}

More commonly it is description of systematic errors, a measure of statistical bias; as these cause a difference between a result and a 'true' value, ISO calls this trueness.

\subsection{N HCl}

\begin{tabular}{|l|l|l|l|}
\hline Conc. & Absorbance & Found Concentration & Recovery (\%) \\
\hline 2 & 0.150 & 2.20339 & $110.169 \%$ \\
\hline 4 & 0.270 & 4.237288 & $105.9322 \%$ \\
\hline 6 & 0.388 & 6.237288 & $103.9548 \%$ \\
\hline 8 & 0.498 & 8.101695 & $101.2712 \%$ \\
\hline 10 & 0.598 & 9.79661 & $97.9661 \%$ \\
\hline
\end{tabular}

\section{$0.1 \mathrm{~N} \mathrm{NaOH}$}

\begin{tabular}{|l|l|l|l|}
\hline Conc. & Absorbance & Found concentration & Recovery (\%) \\
\hline 2 & 0.140 & 2.313725 & 115.6863 \\
\hline 4 & 0.244 & 4.352941 & 108.8235 \\
\hline 6 & 0.338 & 6.196078 & 103.268 \\
\hline 8 & 0.437 & 8.317255 & 101.7157 \\
\hline 10 & 0.528 & 9.921569 & 99.21569 \\
\hline
\end{tabular}

\section{Precision}

Precision of analytical methods were expressed in percentage relative standard deviation (\%RSD) of series of measurements. The intraday and interday precision of the proposed methods were determined by estimating corresponding responses of samples solution on the same day and on other day respectively. Precision was calculated as intraday and interday coefficient of validation.

\section{For HCL:}

(Intraday)

\begin{tabular}{|l|l|l|l|l|l|l|}
\hline Conc. & Trial 1 & Trial 2 & Trial 3 & Mean & SD & \%RSD \\
\hline 2 & 0.175 & 0.177 & 0.171 & 0.174 & 0.003055 & 1.75 \\
\hline 4 & 0.255 & 0.251 & 0.252 & 0.252 & 0.002082 & 0.82 \\
\hline 6 & 0.363 & 0.372 & 0.369 & 0.368 & 0.004583 & 1.24 \\
\hline
\end{tabular}


HCL:

(Interday)

\begin{tabular}{|l|l|l|l|l|l|l|}
\hline Conc. & Trial 1 & Trial 2 & Trial 3 & Mean & SD & \%RSD \\
\hline 2 & 0.180 & 0.179 & 0.177 & 0.178 & 0.001528 & 0.85 \\
\hline 4 & 0.263 & 0.258 & 0.260 & 0.260 & 0.002517 & 0.96 \\
\hline 6 & 0.378 & 0.382 & 0.374 & 0.374 & 0.00400 & 1.05 \\
\hline
\end{tabular}

NaOH:

(Intraday):

\begin{tabular}{|l|l|l|l|l|l|l|}
\hline Conc. & Trial 1 & Trial 2 & Trial 3 & Mean & SD & \%RSD \\
\hline 2 & 0.242 & 0.242 & 0.240 & 0.241 & 0.001155 & 0.4 \\
\hline 4 & 0.203 & 0.204 & 0.198 & 0.201 & 0.003215 & 1.59 \\
\hline 6 & 0.281 & 0.275 & 0.278 & 0.278 & 0.003 & 0.735 \\
\hline
\end{tabular}

NaOH:

(Interday):

\begin{tabular}{|l|l|l|l|l|l|l|}
\hline Conc. & Trial 1 & Trial 2 & Trial 3 & Mean & SD & \%RSD \\
\hline 2 & 0.215 & 0.211 & 0.218 & 0.214 & 0.0035 & 1.64 \\
\hline 4 & 0.213 & 0.209 & 0.212 & 0.211 & 0.002 & 0.98 \\
\hline 6 & 0.282 & 0.286 & 0.283 & 0.283 & 0.0020 & 0.735 \\
\hline
\end{tabular}

\section{Limit of detection (LOD)}

The lowest quantity or concentration of a component that can be reliably detected with a given analytical method.

\subsection{N HCl LOD $=0.9175$ \\ 0.1N NaOH LOD $=1.064$}

\section{Limit of Quantitation (LOQ)}

The LOQ is limit at which the difference between two distinct values can be reasonably discerned.

0.1N HCl LOQ= 2.7803
0.1N NaOH LOQ= 3.2243

\section{RESULT AND DISCUSSION}

A simple, precise, accurate difference spectrophotometric method has been developed for estimation of Amitriptyline in pure and in formulations. The difference spectrum of Amitriptyline in $0.1 \mathrm{~N} \mathrm{HCl}$ and in $0.1 \mathrm{~N} \mathrm{NaOH}$ solutions was recorded and water is taken as blank. The difference spectrum showed at wavelength $239 \mathrm{~nm}$. In alkaline solution, drug shows more intense peak than acidic peak. Therefore DA is positive. Five point calibration graphs were constructed covering a concentration range $2-10 \mu \mathrm{g} / \mathrm{ml}$.

Table 1: Linearity of Amitriptyline Hydrochloride by Difference Spectrophotometry

\begin{tabular}{|l|l|l|l|l|}
\hline Sr.no. & $\begin{array}{l}\text { Concentration of Amitriptyline } \\
\text { Hydrochloride }(\mathbf{m c g} / \mathbf{m l})\end{array}$ & $\begin{array}{l}\text { Absorbance in } \\
\mathbf{0 . 1 N} \text { HCl }\end{array}$ & $\begin{array}{l}\text { Absorbance in 0.1N } \\
\text { NaOH }\end{array}$ & $\begin{array}{l}\text { Difference in } \\
\text { absorbance }\end{array}$ \\
\hline 1 & 2 & 0.150 & 0.140 & 0.01 \\
\hline 2 & 4 & 0.270 & 0.244 & 0.026 \\
\hline 3 & 6 & 0.388 & 0.338 & 0.046 \\
\hline 4 & 8 & 0.498 & 0.437 & 0.061 \\
\hline 5 & 10 & 0.598 & 0.528 & 0.071 \\
\hline
\end{tabular}

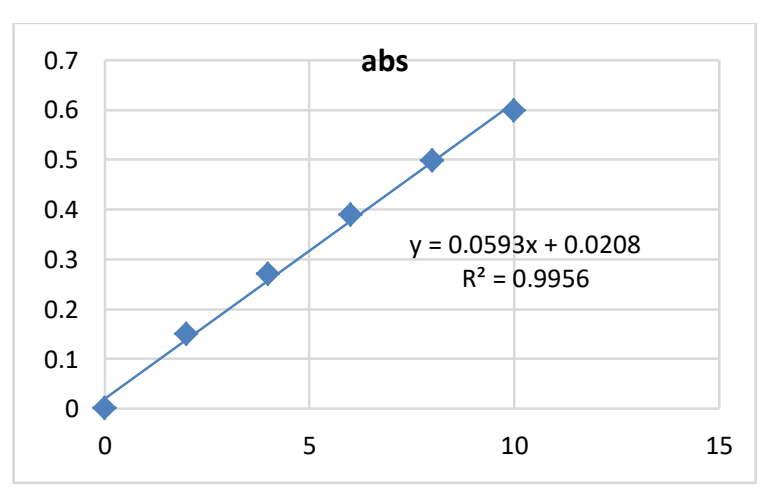

Figure3: Linearity of Amitriptyline $\mathrm{HCl}$ in $0.1 \mathrm{~N} \mathrm{HCl}$ 


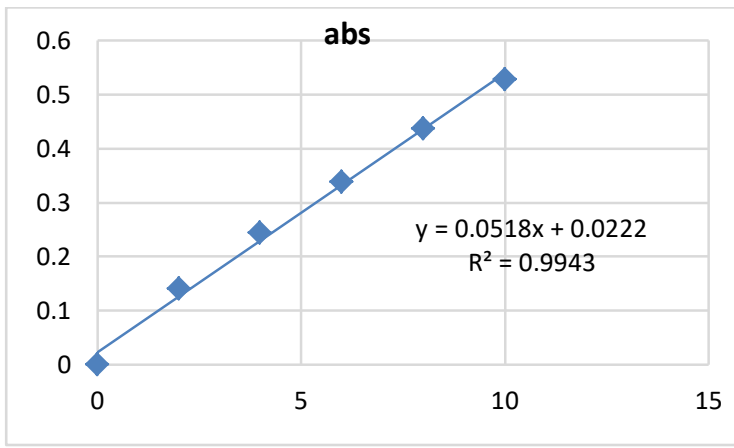

Figure 4: Linearity of Amitriptyline in $0.1 \mathrm{~N} \mathrm{NaOH}$

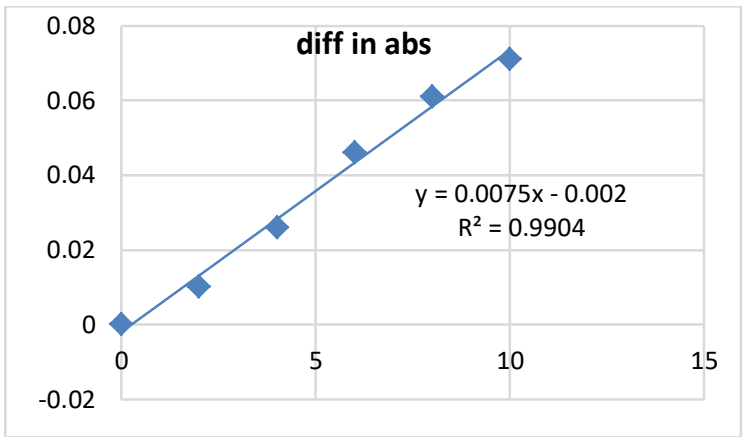

Figure 4: Difference in Absorbance

\section{CONCLUSION}

The proposed method is simple, accurate, precise and selective for the estimation of amitriptyline hydrochloride in bulk drug. The method is economical, rapid and do not require any sophisticated instruments contrast to chromatographic method. Hence, it can be effectively applied for the routine analysis of amitriptyline hydrochloride in bulk drug.

\section{ACKNOWLEDGEMENT}

It is the moment of great pleasure for us to express our deep gratitude and gratefulness towards Mr. A. M. Tamboli, assistant professor in Pharmaceutical chemistry, Dr. M.S Patil, Principal of S.C.P.M. Sangola, for their guidance throughout this work.

We are also thankful to Research Lab fine chemicals, Mumbai and Poona chemicals laboratory for providing the drug sample and chemicals without which this work was not possible to carry out.

\section{REFERENCES}

1. "Indian Pharmacopoeia" Govt. of India, Ministry of Health \& Family Welfare, Delhi, vol-2, 2007; 712.

2. Beckett A.H. and Stenlake J.B. Practical Pharmaceutical Chemistry Fourth edition - part two CBS publishers and Distributors. 293-294

3. Validation of Analytical Procedures: Text and Methodology Q2 (R1). ICH Harmonised Tripartite Guideline. Oct.1994.

4. Validation of Analytical Procedure: Text and methodology, ICH Harmonised Tripartite Guideline, Q2 (R1), 2005.

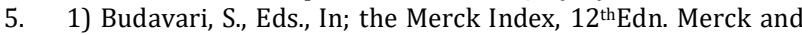
Co.Inc., Whitehouse Station. NJ, 1996, 1971.

6. 2) Mine, Y., Wantanabe, Y., Matsumoto, Y., Kuno, K., Hantano, K., Higashi, Y., and Kuwahara, S., Chemotherapy, 1989, 37, 122.

7. 3) Okamoto, Y., Itoh, K., Namiki, Y., Matsushita, J., Fujioka, M., and Yasada, T., J. Pharm. Bio. Med. Anal. 1996, 14, 739.Cohen, C. and Michael, N., Dig. Microbiol. Infect. Dis., 1994, 18, 31.

8. 4) Gandhimathi, M., Suganthi, A., Ravi, T.K. and Minu B., In dian J.Pharm.Sci., 2004, 66, 248.

9. 5) Smith, R.V. and Stewart, J.T., In; Text book of Biopharmaceutic Analysis, Lea and Febiger, Philadelphia, 198, 138.

10. Adat Priyanka et al. Stability indicating UV spectrophotometric method for simultaneous estimation of Montelukast sodium and Theophyline in combined pharmaceutical formulations. Int. Res.J. Pharm. 2018;9(8). 